\title{
ANALISIS AKTOR DALAM PEMBENTUKAN KEBIJAKAN PENGAKUAN MASYARAKAT HUKUM ADAT PASCA PUTUSAN MK 35 (Studi atas Peran AMAN dan Jaringannya dalam Mendorong Pengakuan Masyarakat Hukum Adat Melalui UU Desa dan RUU PPMHA)
}

\author{
Analysis of Actors in Promoting Recognition of Indigenous Peoples Policy Post Constitution \\ Court Rulling No.35 (Study on AMAN's and the Network's Role in Promoting the Recognition \\ of Indigenous Peoples Through Village Law and Recognition and \\ Protection of Indegenous People Bill)
}

Idham Arsyad*), Satyawan Sunito dan Haryadi Kartodiharjo

Program Studi Sosiologi Pedesaan, Fakultas Ekologi Manusia, Sekolah Pascasarjana IPB

${ }^{*}$ E-mail: idham.arsyad15@gmail.com

\begin{abstract}
The judicial review allegation conducted by the Nusantara Indigenous Peoples Alliance (AMAN) against Act No. 41/1999 on Forestry has resulted Constitutional Court Rulling No.35 (Putusan MK 35) which sucessfully excluded indigenous forests from the state forest. This ruling has implications for the process of new policy formulation related to the recognition and protection of indigenous people and their customary land. Therefore this study aims to look at the influence of the Putusan MK 35 on the formulation of the Village Law and Recognition and Protection of Indegenous People Bill (RUU PPMHA)through the role of actors and discourses. This study found that; The Putusan MK 35 affect the substance of the Village Law with the inclusion of the indegenous village nomenclature within the law. A common discourse and political interests among actors made the Village Law formed quickly. However the rulling did not succeed in promoting PPMHA Law given the conflict of the actors was very high and the discourse about social unit of indegenous people was unclear at that time
\end{abstract}

Keywords: indigenous peoples, indigenous forest, indigenous village, recognition and protection, costumary land

\begin{abstract}
ABSTRAK
Gugatan judicial review yang dilakukan oleh Aliansi Masyarakat Adat Nusantara (AMAN) terhadap UU No.41 tahun 1999 tentang Kehutanan yang menghasilkan Putusan Mahkamah Konstitusi No.35 (Putusan MK 35) yang mengeluarkan hutan adat dari hutan negara. Kebijakan ini berimplikasi pada proses pembentukan kebijakan baru terkait dengan pengakuan dan perlindungan masyarakat adat dan wilayah adatnya. Karenanya, penelitian ini bertujuan untuk melihat pengaruh Putusan MK 35 terhadap Undang-Undang tentang Desa dan Rancangan Undang-Undang tentang Pengakuan dan Perlindungan Masyarakat Hukum Adat (RUU PPMHA) melalui analisis aktor dan diskursus yang berkembang. Penelitian menemukan bahwa Putusan MK 35 mempengaruhi subtansi Undang- Undang Desa dengan masuknya nomenklatur desa adat dalam undang-undang. Diskursus dan kepentingan yang saya sama dari aktor membuat undang-undang ini terbentuk secara cepat. Namun tidak berhasil dalam RUU PPMHA karena konflik para aktor sangat tinggi dan diskursus mengenai unit sosial masyarakat hukum adat tidak jelas.
\end{abstract}

Kata kunci: masyarakat adat, hutan adat, desa adat, pengakuan dan perlindungan, wilayah adat.

\section{PENDAHULUAN}

Sejarah penguasaan negara atas lahan hutan telah dimulai sejak masa kolonial. Secara umum tiga tahap dilakukan oleh pemerintah kolonial untuk menguasai hutan, yakni : Pertama, pemerintah kolonial menetapkan Boschordonantie voor java en madoera pada tahun 1865 , kemudian dilanjutkan dengan menerapkan peraturan Domeinverklaring pada tahun 1870. Pada tahap ini, semua lahan hutan dimasukkan menjadi milik negara kecuali yang terdapat penguasaan pribadi di dalamnya. Kedua, Jawatan Kehutanan Belanda (Dienst van hetBoschwezen) menetapkan batas-batas antara lahan pertanian dengan lahan hutan, dan menetapkan lahan hutan yang dimiliki dan dikendalikan oleh pemerintah kolonial. Tahap ini ditandai dengan penetapan kawasan hutan secara politik (political forest) ${ }^{1}$ dan diperinci kewenangan badan pemerintah dalam mengelola hutan. Dan tahap ketiga, hutan 1 Istilah hutan politik (political forest) dikenalkan oleh Peluso dan Vandergeest (2001). dibagi berdasarkan fungsi-fungsi kehutanan yang ditentukan berdasarkan kriteria fungsi maupun karakteristik ketinggian, kemiringan, dan sebagainya. Pada tahap ini pemerintah kolonial menetapkan zonasi dan aktivitas atau usaha yang boleh dilakukan pada setiap zona (Rachman dan Siscawati 2014).

Pasca kolonial, pemerintah Indonesia, khususnya era pemerintahan Soeharto mengadopsi praktik penguasaan hutan dan sistem hukum yang dijalankan oleh Pemerintahan kolonial. Pengendalian negara atas wilayah hutan di era ini dimulai dengan mengeluarkan UU Nomor 5 tahun 1967 tentang Ketentuan-Ketentuan Pokok Kehutanan. Dimana UU Kehutanan ini justru menghidupkan kembali asas domein bahwa semua lahan dalam "kawasan hutan" adalah milik negara, dan Menteri Kehutanan yang mempunyai kewenangan penuh untuk menetapkan kawasan hutan tersebut, yang sejatinya telah dihapuskan oleh UU Nomor 5 tahun 1960 tentang Peraturan Dasar Pokok-pokok Agraria (UUPA) dan 
digantikan dengan politik hukum "Hak Menguasai dari Negara" (Rachman dan Siscawati 2014).

Pasca reformasi, asas domein ini terus dilanjutkan melalui UU Nomor 41 tahun 1999 tentang Kehutanan. Penguasaan negara atas wilayah hutan telah berdampak buruk pada kehidupan kelompok-kelompok masyarakat di dalam kawasan, yang sebagian besar masyarakat adat. UU Nomor 41 tahun 1999 tentang Kehutanan yang memasukkan hutan adat ke dalam hutan negara telah mengakibatkan ruang hidup masyarakat adat semakin menyempit bahkan sebagian telah tersingkir dari wilayah penghidupan mereka, serta terus mengalami proses kriminalisasi dan konflik agraria (Ruwiastuti et al.1997; Moniaga 2010; Rachman 2014).

Menghadapi proses kriminalisasi, penyingkiran dan konflik yang berkepanjangan mendorong masyarakat adat melakukan beragam bentuk perlawanan. Mulai dari aksi perebutan lahan hutan di tingkat lokal, advokasi perubahan kebijakan nasional hingga membangun jaringan komunikasi dan solidaritas untuk mendapatkan dukungan di tingkat Internasional. Salah satu wujud dari perlawanan tersebut adalah advokasi perubahan kebijakan dengan melakukan gugatan judicial review terhadap Pasal 1 angkat 6 dan beberapa Pasal lainnya dalam UU Nomor 41 tahun 1999 tentang Kehutanan oleh Aliansi Masyarakat Adat Nusantara (AMAN) bersama dua kesatuan masyarakat hukum adat anggotanya.

Pada Tanggal 16 Mei 2013, Mahkamah Konstitusi Republik Indonesia mengabulkan sebagian gugatan AMAN dan dua kesatuan masyarakat hukum adat dengan memutuskan bahwa "hutan adat adalah hutan yang berada dalam wilayah masyarakat hukum adat" dan hutan adat tidak lagi menjadi bagian dari hutan negara melainkan bagian dari hutan hak. Putusan MK 35 ini sebagai norma konstitusi menegaskan tiga hal yang berkaitan dengan pengakuan dan perlindungan masyarakat hukum adat, yakni: 1) Masyarakat hukum adat sebagai subjek hukum, 2) masyarakat hukum adat sebagai penyandang hak, dan 3) Masyarakat hukum adat sebagai pemegang wilayahnya.

Keputusan Mahkamah Konstitusi ini (kemudian dikenal dengan sebutan MK 35) mendapat respon beragam tidak hanya dari masyarakat adat, tetapi juga dari pemerintah serta pelaku usaha kehutanan. Selain itu, Putusan MK 35 ini juga mempengaruhi proses pembentukan kebijakan yang sedang berlangsung pada saat yang bersamaan, yakni penyusunan Rancangan Undang-Undang Desa dan Rancangan UndangUndang Pengakuan dan Perlindungan Masyarakat Hukum Adat. Diterima tidaknya subtansi Putusan MK 35 terhadap proses pembentukan perundang-undangan sangat bergantung pada dinamika dan aktor politik yang mempengaruhinya. Pada UU No.6 tahun 2014, Putusan MK 35 mempengaruhi subtansi UU Desa dengan dinormakannya desa adat. Sedangkan pada RUU Perlindungan dan Pemberdayaan Masyarakat Hukum Adat, Kementerian Kehutanan yang ditunjuk oleh Presiden Susilo Bambang Yudhoyono sebagai penerima Amanat Presiden (AMPRES) tidak melakukan suatu proses percepatan hingga masa bakti DPR periode 2009-2014 berakhir. Berdasar atas latar belakang tersebut di atas, maka penelitian ini akanmemusatkan perhatian pada pertanyaan-pertanyaan sebagai berikut:

1. Bagaimana Pengaruh Putusan MK 35 terhadap pembentukan kebijakan agraria, pada UU Desa dan RUU PPMHA?

2. Bagaimana AMAN dan koalisi pendukungnya menggunakan putusan MK 35 untuk mempengaruhi UU Desa dan RUU PPMHA?

\section{PENDEKATAN TEORI}

\section{Proses Pembuatan Kebijakan}

Selama ini, proses pembuatan kebijakan banyak menggunakan model linier (linear model) yang menjelaskan bahwa proses pembuatan kebijakan itu berlangsung secara rasional, seimbang, objektif dan analisis. Proses pembuatan kebijakan pada model linier ini dimaknai sebagai serangkaian kegiatan yang berurutan, mulai dari mengidentifikasi masalah dan berakhir dengan serangkaian kegiatan pemecahan dari masalah (Sutton 1999). Pada model linier ini, proses pembuatan kebijakan melalui tahap-tahap sebagai berikut: 1) Mengenali dan mendefinisikan masalah yang akan ditangani; 2) Mengidentifikasi program aksi yang memungkinkan untuk menangani masalah; 3) Menganalisis atau menghitung keuntungan dan kerugian darim masing-masing alternatif penyelesaian masalah; 4) Memilih opsi opsi yang menawarkan solusi yang terbaik; 5) Menerapkan kebijakan, dan 6) Mengevaluasi hasil kebijakan (Sutton 1999).

Model linier ini dikritik oleh Institute Development Studies (IDS). Berdasarkan hasil penelitiannya, IDS mengungkapkan bahwa bahwa proses pembuatan kebijakan tidak bisa lagi dipahami sebagai suatu proses linier dan menggunakan pendekatan rasional (IDS 2006). Lebih jauh, IDS mengemukakan bahwa pendekatan linier ini tidak lagi relevan untuk melihat sebuah kebijakan, karena proses pembuatan kebijakan mempunyai karateristik, antara lain :Pertama, bahwa proses pembuatan kebijakan harus dipahami sebagai suatu proses politik, bukan perkara teknis atau perbuatan rasional semata. Kedua, bahwa proses pembuatan kebijakan berlangsung secara gradual, berulang, dan merupakan tindakan belajar dari kesalahan (trial and error) sehingga keputusannya tidak bersifat optimal. Ketiga, bahwa dalam proses pembuatan kebijakan selalu terdapat agenda yang tumpang tindih dan saling berkompetisi. Keempat, bahwa dalam proses pembuatan kebijakan selalu mencakup beberapa perspektif dengan mengorbankan dan menyingkirkan perspektif orang miskin dan orang yang termarinalkan (IDS 2006).

Mengadaptasi hasil penelitian IDS tersebut di atas, Kartodiharjo (2013) mengemukakan bahwa dalam proses pembuatan kebijakan perlu memperhatikan tiga hal, yakni:Pertama, diskursus yang digunakan untuk menetapkan suatu masalah dan solusinya, mengapa sesuatu dianggap sebagai masalah oleh sekelompok orang dan bukan masalah oleh sekelompok lainnya. Mengapa dengan masalah yang sama sekelompok orang menentukan solusi berbeda dengan kelompok orang lainnya.

Kedua, politik dan kepentingan atas ditetapkannya suatu kebijakan. Hal ini untuk menegaskan bahwa diskursus yang digunakan dalam proses pembuatan kebijakan meskipun itu didasari dari hasil penelitian sesungguhnya tidaklah netral atau bebas nilai. Terdapat hubungan timbal balik antara diskursus dan kepentingan. Kartodiharjo (2013) mencontohkan bahwa konsep atau teori yang digunakan oleh seorang akademisi, disadari atau tidak akan digunakan oleh sekelompok orang yang kepentingannya terdukung oleh kajian tersebut. Sebaliknya, sekelompok orang akan memaksakan menggunakan diskursus yang tercermin dalam teori, konsep atau pendekatan untuk menentukan masalah dan solusi kebijakan yang sedang ditetapkan oleh pemerintah. Artinya bahwa teori, konsep atau pendekatan yang digunakan untuk menetapkan suatu kebijakan sangat bergantung kepada kelompok politik dan kepentingan yang bertarung. 
Ketiga, aktor yang mempromosikan dan jaringan kerjanya. Keberadaan aktor dan jaringan sangat menentukan apakah suatu kebijakan dapat tercapai atau tidak. Dalam hal ini sangat bergantung pada kekuatan dari kedudukan, posisi dan sumber daya (kekuasaan, kewenangan, anggaran, kekayaan, dll) masing-masing aktor dan jaringannya dalam mempengaruhi suatu kebijakan. Aktor dan jaringan ini terbentuk karena kesamaan visi dan kepercayaan serta kode etik dan kebiasaan yang terbangun. Melalui aktor dan jaringan ini, praktek dari norma yang baik dan buruk dipertahankan, agenda penelitian ditetapkan, kearifan ortodoks dan konvesional ditetapkan (IDS 2006).

Memamhami proses pembuatan kebijakan melalui pemeriksaan terhadap pengetahuan dan diskursus, aktor dan jaringan serta politik dan kepentingan dapat membantu untuk mengidentifikasi ruang kebijakan (policy space). Ruang kebijakan adalah ruang yang tersedia yang memungkinkan suatu kebijakan terbentuk atau berubah dengan melihat sejauh mana kontestasi antara diskursus, aktor dan jaringan serta politik dan kepentingan berlangsung. Artinya, seperti yang dikemukakan Lubell (2004) dan Kartodiharjo (2008) bahwa perubahan-perubahan kebijakan sangat bergantung pada kemampuaan suatu diskursus tertentu apakah dapat membangkitkan ide-ide baru dan diterima berbagai aktor atau tidak. Hal ini berarti bahwa hanya hanya diskursus, aktor dan kepentingan politik yang sama yang membuat dan mengubah kebijakan dari waktu ke waktu (Kartodiharjo 2006).

\section{Kebangkitan Gerakan Masyarakat Adat}

Kebangkitan kembali gerakan masyarakat adat di berbagai wilayah pasca kejatuhan presiden Soeharto telah banyak dituliskan beberapa penulis, seperti dikutip oleh Davidson et al. (2010): a. kebangkitan adat di Sumatra Barat (Fanz dan Beckmann 2001), b. Ricard (2005) kebangkitan adat tentang Bali, c. Avonius (2004) tentang kebangkitan adat di Lombok, d. Roth (2002) tentang Sulawesi Selatan, e.Timmer (2005) tentang Papua, f. Dan karya Acciaioli $(2001,2002)$ dan Li (2000, 2001) yang mengkaji tentang gerakan masyarakat adat hubungannya dengan masyarakat adat di Internasional. Dan buku adat dalam politik indonesia yang disunting oleh Davidson et al. (2010) menggambarkan kebangkitan adat kontemporer dalam konteks pembentangan adat dalam politik masa lampau di Indonesia.

Kebangkitan kembali gerakan masyarakat adat di Indonesia didorong oleh empat faktor (Henley dan Davidson 2010), yakni: Pertama, pengaruh dunia internasional. Kebangkitan gerakan masyarakat adat di berbagai belahan dunia, selain sebagai kelanjutan dari gerakan anti-imperialisme (Lohman 1993; Wilmer 1993), juga didorong oleh kekecewaan terhadap model-model universal tentang kemajuan manusia dan proyekproyek raksasa, seperti nasionalisme dan sosialisme, sehingga mendorong simpati baru di sejumlah negara-negara maju atas penurunan kualitas hidup yang dialami oleh kelompokkelompok etnis dan indigenitas, yang kemudian mendapatkan dukungan dari gerakan pecinta lingkungan.

Kebangkitan gerakan masyarakat adat di dunia juga ditandai dengan munculnya gerakan pembelaan terhadap masyarakat adat di beberapa negara maju seperti di Amerika Serikat, kemudian diikuti dengan kelahiran sejumlah gerakan proxy (proxy movement) yang mengatasnamakan masyarakat adat di negara-negara berkembang, misalnya lahirnya The International Work Goup For Indigenous Affairs di Denmark tahun 1968, Survival International di Inggris tahun 1969, dan Cultural Survival di Amerika tahun 1976 (Henley dan Davidson 2010). Suatu pencapaian luar biasa dari gerakan masyarakat adat di dunia karena berhasil membuat sejumlah kesepakatan dan deklarasi yang diprakarsai oleh organisasiorganisasi dunia. Misalnya, Perserikatan Bangsa-Bangsa (PBB) membentuk kelompok kerja PBB untuk masyarakat adat pada tahun 1982 yang mempublikasikan sejumlah studi tentang persoalan hak-hak masyarakat adat (indigenous rights), Pada tahun 1989, Organisasi Buruh Internasional mengeluarkan konvensi No.169 yang menolak pendekatan asimilasi terhadap indigenous rights. Kemajuan gerakan masyarakat adat juga mulai terlihat di beberapa negara, misalnya di seluruh belahan Amerika Latin, pemerintah mulai meninggalkan kebijakan integrasi paksa. Tahun 1992, Pengadilan Tinggi Austarliamengakui hak-hak aboriginal atas tanah (Henley dan Davidson 2010).

Kedua, tekanan dan penindasan yang dialami oleh masyarakat adat di bawah pemerintahan orde baru menjadi salah satu faktor pendorong kebangkitan adat. Di beberapa wilayah di Indonesia, kebangkitan adat ditunjukkan dengan semakin menguatnya tuntutan atas pengakuan dan pengembalian wilayah adat yang telah dirampas di masa pemerintahan Orde Baru, serta tuntutan untuk mengembalikan melaksanakan aturan dan praktik kelembagaan berdasarkan hukum adat. Situasi yang kemudian dipandang sebagai musuh yang memicu kebangkitan gerakan adat di berbagai wilayah Indonesia sangat berbeda-beda. Tetapi secara umum dimulai dengan penetapan suatu program nasional yang berimplikasi pada perampasan dan pengambilalihan tanah-tanah adat mereka. Di beberapa wilayah di Sulawesi, Kalimantan dan Papua, kebijakan pertambangan, perkebunan dan kehutanan menjadi musuh utama masyarakat adat, sedangkan di Bali program proyek skala besar dalam sektor pariwisata dan real state menjadi musuh utama mereka.

Ketiga, era reformasi yang ditandai dengan kejatuhan Presiden Soeharto pada Mei 1998 yang membuka kran kebebasan politik menjadi ruang bagi kebangkitan gerakan masyarakat adat di Indonesia. Kebangkitan gerakan masyarakat adat selain ditandai dengan gerakan penuntutan kembali atas tanahtanah yang telah dijadikan areal pertambangan, kehutanan dan berbagai bentuk pembangunannya lainnya di era pemerintahan Orde Baru dengan atas nama hukum adat bukan hukum negara, juga ditandai dengan perkembangan pesat dari organisasi nonpemerintah yang kemudian mempunyai relasi yang kuat dalam mendorong kelahiran Aliansi Masyarakat Adat Nusantara (Hadiwinata 2003 dalam Henley dan Davidson 2010).

Faktor Keempat yang mempengaruhi kebangkitan adat adalah apa yang disebut oleh Henley dan Davidson (2010) sebagai warisan-warisan ideologi yang bersifat kesejarahan yang membedakan suatu sistem hukum dan kemasyarakat antara era kolonialisme dan era kemenderkaan Indonesia. Beberapa konsepsi yang identikkan dengan adat, seperti: Komunalisme, kolektivisme, gotong royong, musyawarah mufakat dan azas keluargaan di awal-awal masa kemerdekaan menjadi propaganda untuk melawan hal-hal yang bersifat 'barat'.

\section{METODE PENELITIAN}

Penelitian ini adalah penelitian tentang pembentukan kebijakan di level nasional dengan unit analisinya Aliansi Masyarakat Adat Nusantara yang berlokasi di Jakarta. Penelitian dilakukan selama 3 bulan, April-Juni 2016. Paradigma yang digunakan penelitian ini adalah teori kritis (critical theory). 
Dalam paradigma teori kritis, realitas bersifat historis. Karena dibentuk oleh proses sejarah. Sehingga paradigma kritis mengakui dan memberi ruang pada sifat-sifat objektif dari realitas. Dalam paradigma ini, peneliti melakukan dialog intersubjektif dengan tineliti, termasuk pada aras aksiologis, untuk apa penelitian ini dilakukan.

Makna interpretatif menjelaskan bahwa setiap ungkapan memiliki semantis terhadap maksud peneliti dalam lingkup kebudayaan ditempat penelitian dilakukan. Sifat otonom semantis yang dilakukan peneliti berkaitan dengan konsekwensi penting bagi penafsiran sebuah teks (dalam makna ini, realitas adalah teks). Dengan demikian tujuan penafsiran bukan seperti maksud peneliti, melainkan arti yang terberi dan terungkap dalam dan melalui realitas/teks. Sebagaiamana dijelaskan Suseno (1992) tujuan teori kritis adalah untuk menjelaskan dan memetakan realitas sosial dengan jernih dan analitik. Dengan paradigma kritis, studi ini diharapkan dapat mengurai dan menjelaskan dinamika pertarungan kepentingan, aktor dan diskursus yang yang berkembang dalam proses pembuatan kebijakan agraria kehutanan di level nasional dan relasinya dengan gerakan masyarakat adat yang direpresentasikan oleh Aliansi Maasyarakat Adat Nusantara pasca putusan Mahkamah Konstitusi No.35/PUU-IX/21.

Penelitian ini menggunakan metode kualitatif dengan pendekatan studi kebijakan guna memudahkan mendapatkan data dalam waktu yang singkat. Data yang digunakan dalam penelitian adalah data primer dan data sekunder. Data primer dikumpulkan melalui wawancara mendalam dengan informan. Data sekunder dikumpulkan melalui dokumen Naskah Akademik dan RUU (UU Desa dan RUU PPMHA) dan dokumen yang terkait dengan penelitian. Pemilihan informan dilakukan secara purposive. Informan yang dipilih merupakan informan yang paling mengetahui dan menguasai permasalahan serta terlibat dalam proses pembentukan kebijakan. Informan yang berhasil diwawancarai berasal dari: Pengurus Aliansi Masyarakat Adat Nusantara (AMAN), Aktivis dan NGO yang terlibat membantu perjuangan AMAN serta terlibat dalam penyusunan UU Desa dan RUU PPMHA, Kementerian Lingkungan Hidup dan Kehutanan, Tim Ahli Pansus RUU dan Hakim Mahkamah Konstitusi.Data-data yang diperoleh dari hasil wawancara dikumpulkan dengan pencatatan yang dilakukan setiap harinya disebut catatan harian. Hasil catatan harian tersebut kemudian direduksi untuk mencari informasi-informasi yang sesuai dengan kebutuhan penelitian.

\section{HASIL DAN PEMBAHASAN}

\section{Dinamika Perjuangan AMAN dalam Menuntut Pengakuan Wilayah Adat: dari Arena Lokal ke Arena Nasional}

Kehadiran Aliansi Masyarakat Adat Nusantara (AMAN) sangat berhubungan dengan kondisi sosial politik di era Pemerintahan Republik Indonesia yang dipimpin oleh PresidenAbdurahman Wahid (Gus Dur). Cikal bakal gerakan masyarakat adat muncul sekitar tahun 1980-an, yang merupakan andil dari para aktivis lingkungan hidup dan hak asasi manusia, yang pada gilirannya pada tahun 1993 kalangan CSO menginisiasi suatu pertemuan di Toraja Sulawesi Selatan yang mereka memproklamirkan diri sebagai JAPHAMA (Jaringan Pembela Hak-hak Masyarakat Adat).

Definisi masyarakat adat sendiri yang diambil sebagai simbol gerakan politik memiliki pengertian beragam. Pada Kongres AMAN I tahun 1999 terminologi masyarakat adat didefinisikan sebagai komunitas-komunitas yang hidup berdasarkan asalusul leluhur secara turun temurun di atas suatu wilayah adat, yang memiliki kedaulatan atas tanah dan kekayaan alam, kehidupan sosial budaya, yang diatur oleh hukum adat dan lembaga adat yang mengelola keberlangsungan kehidupan masyarakatnya. Atas dasar definisi ini, maka AMAN mengklaim bahwa sebaran anggotanya di Indonesia mencapai $50-70$ juta jiwa.

Gerakan AMAN lahir dari perlawanan rakyat lokal terkait kontestasi pengelolaan dan penguasaan sumberdaya alam di Indonesia. Akar kontestasi itu muncul dalam karakter perlawanan diam-diam sampai pada perlawanan fisik, termasuk yang dikemukakan oleh Afif dan Lowe (2007), bahwa gerakan masyarakat adat menggabung protes-protes dengan pendekatan etnisitas. Menurut Fauzi (2005) beberapa faktor kunci kemunculan gerakan AMAN, antara lain: akumulasi perlawanan masyarakat adat, transisi politik, kekuatan media massa, dan dukungan ornop (nasional dan internasional). Kesemuanya merupakan faktor yang memberi jalan tempuh ekspansi gerakan-gerakan lokal menuju aksi kolektif nasional. Gerakan AMAN juga tidak bisa dilepas-pisahkan dari dua entitas gerakan lainnya yakni gerakan lingkungan dan gerakan agraria yang telah menghiasi ranah gerakan sosial sejak era tahun 1970-an. Ornop-ornop yang terlibat dalam membidani lahirnya AMAN merupakan ornop yang berafiliasi pada isuisu lingkungan dan agraria. Pada ranah advokasi kebijakan, keduanya selalu bersandar pada tuntutan implementasi Undang-Undang Pokok Agraria.

Lebih detail dari analisis di atas, Fauzi dan Siscawati (2014) mengupas ulang akar sejarah kelahiran Gerakan AMAN berdasarkan dokumen-dokumen resmi yang dikeluarkan oleh Kongres AMAN I Tahun 1999 bahwa masalah-masalah yang dihadapi sangat melimpah dalam pengalaman komunitaskomunitas adat di seantero nusantara, seperti: pada bidang politik, lembaga-lembaga adat yang menjadi pengatur masyarakat adat diporak-porandakan dengan dipaksakannya lembaga-lembaga pemerintahan daerah dan desa yang berlaku seragam untuk seluruh wilayah berdasarkan Undang-Undang Pemerintahan Daerah Nomor 5 tahun 1974 dan UndangUndang Pemerintahan Desa Nomor 5 tahun 1979. Konsep "desa" yang dipaksakan itu, telah menimbulkan konflik yang hebat dalam masyarakat yang telah memiliki otonomi sistem pemerintahan adat tersendiri; pada bidang hukum, konsep penguasaan Negara atas bumi, air, dan kekayaan alam yang terkandung didalamnya telah menjadi suatu alat yang ampuh menghilangkan kedaulatan masyarakat adat. Berbagai undang-undang, seperti UU No.5/1960, UU No.5/1967, UU No.11/1967, selalu mendasarkan diri pada konsep Hak Menguasai Negara yang merupakan wujud dari kekuasaan negara mengambil alih kedaulatan masyarakat adat atas tanah dan kekayaan alamnya; pada bidang sosial budaya, berbagai pengetahuan dan kearifan lokal milik masyarakat adat telah dilecehkan, dihilangkan dan dicuri. Pemahaman dan penguasaan masyarakat adat atas kekayaan alamnya yang telah dihancurkan oleh kebijakan-kebijakan yang memaksakan keseragaman kehidupan sosial budaya; dari perspektif gender, kehidupan perempuan dalam masyarakat adat makin tertindas dan menderita seperti meningkatnya beban kerja perempuan adat akibat hilangnya tanah dan kekayaan alam, kekerasan langsung berupa pelecehan dan pemerkosaan.

Putusan MK 35: Penegasan Norma Konstitusi atas Masyarakat Hukum Adat dan Wilayahnya

Putusan Mahkamah Konstitusi Republik Indonesia atas 
Perkara Nomor 35/PUU-X/2012 atau disingkat dengan Putusan MK 35 adalah keputusan majelis hakim konstitusi terhadap permohonan pengujian yang diajukan oleh Aliansi Masyarakat Adat Nusantara (AMAN) bersama dengan Kesatuan Masyarakat Hukum Adat Kenegerian Kuntu dan Kesatuan Masyarakat Hukum Adat Kasepuhan Cisitu atas sejumlah pasal yang terdapat dalam Undang-Undang Nomor 41 tahun 1999 tentang Kehutanan, yakni mencakup : Pasal 1 angka 6, Pasal 4 ayat (3), Pasal 5 ayat (1), ayat (2) dan ayat (3), serta Pasal 67 ayat (1) ayat (2) dan ayat (3). Permohonan pengujian ini diajukan pada 19 Maret 2012 yang diterima di Kapaniteraan Mahkamah Konstitusi pada tanggal 26 Maret 2012 dan tercatat dalam Buku Registrasi Perkara Konstitusi pada tanggal 2 April 2012 dengan Nomor Perkara 35/ PUU-X/2012 (MK 2012).

Putusan MK 35 ini adalah keputusan yang menegaskan kembali posisi dan status masyarakat hukum adat sebagaimana telah termaktub dalam Pasal 18B ayat (2) UUD 1945. Terdapat tiga hal penting dari keputusan MK yang berkaitan pengakuan masyarakat hukum adat, yakni: pengakuan bahwa masyarakat hukum adat adalah penyandang hak, subjek hukum tersendiri dan pemilik wilayah adatnya. Melalui putusannya, MK meralat atas kekeliruan yang telah dipraktikan oleh Pemerintah melalui Kementerian Kehutanan karena telah memasukkan hutan adat ke dalam kategorisasi hutan negara yang mengakibatkan masyarakat hukum adat mengalami kriminalisasi ketika hendak mengambil manfaat dan akses atas sumber daya hutan (Fauzi 201: 27). MK menegaskan kembali norma konstitusi yang memberi pengakuan terhadap keberadaan masyarakat hukum adat dengan mengatakan bahwa UU Kehutanan yang memasukkan hutan adat dalam kategorisasi hutan negara bertentangan dengan Pasal 18B ayat (2) UUD 1945 yang berbunyi: “ Negara mengakui dan menghormati kesatuan-kesatuan masyarakat hukum adat beserta hak-hak tradisionalnya sepanjang masih hidup dan sesuai dengan perkembangan masyarakat dan prinsip Negara Kesatuan Republik Indonesia, yang diatur dalam undangundang. Penegasan MK ini dapat dilihat melalui putusannnya yang mengatakan:

\begin{abstract}
"Dalam ketentuan konstitusional tersebut, terdapat satu hal penting dan fundamental dalam lalu-lintas hubungan hukum. Hal penting dan fundamental tersebut adalah masyarakat hukum adat tersebut secara konstitusional diakui dan dihormati sebagai penyandang hak yang dengan demikian tentunya dapat pula dibebani kewajiban. Dengan demikian masyarakat hukum adat adalah subjek hukum. Sebagai subjek hukum di dalam suatu masyarakat yang telah menegara maka masyarakat hukum hukum adat haruslah mendapat perhatian sebagaimana subjek hukum yang lain ketika hukum hendak mengatur, terutama mengatur dalam rangka pengalokasian sumber-sumber kehidupan" MK (2013: 168).
\end{abstract}

Keberadaan Undang-Undang Kehutanan pada dasarnya adalah bentuk penyangkalan terhadap kedudukan masyarakat hukum adat sebagai penyadang hak dan pemilik wilayah adatnya. Atas dasar itu, Putusan MK 35 melakukan koreksi terhadap ketentuan tersebut dengan memulihkan keberadaan masyarakat hukum adat. Dalam hal ini kita bisa melihat dalam melalui keputusan-keputusannya, sebagai berikut:Pertama, MK menegaskan bahwa telah terjadi perbedaan perlakuan dan tindakan atas subjek-subjek hukum, dimana pemerintah dan perusahaan pemegang hak atas tanah sebagai subjek hukum diatur dengan jelas hubungan mereka terhadap hak tanah maupun hutan, sementara masyarakat hukum adat tidak jelas pengaturannya.

Kedua, bahwa rumusan Penjelasan atas Pasal 5 ayat (1) UU Kehutanan juga merupakan bentuk penyangkalan terhadap status masyarakat hukum adat sebagai penyandang hak dan pemilik wilayah adanya, karena ketentuan tersebut secara nyata merupakan perbuatan memasukkan wilayah adat dalam kategori hutan negara. Atas rumusan Penjelasan atas Pasal 5 ayat (1) UU Kehutanan tersebut, MK (2012: 181) berpendapat, bahwa: "Dalam penilaian hukum terhadap Pasal 5 ayat (1) UU Kehutanan, Mahkamah Konstitusi berpendapat bahwa hutan hak harus dimaknai bahwa hutan hak terdiri dari hutan adat dan hutan perseorangan/badan hukum. Dengan demikian, hutan adat termasuk dalam kategori hutan hak, bukan hutan negara; Berdasarkan pertimbangan hukum di atas, menurut Mahkamah, Penjelasan Pasal 5 ayat (1) UU Kehutanan bertentangan dengan UUD 1945".

Ketiga, MK tidak membenarkan atas penggunaan dan penyalahgunaan konsep "Hak Menguasai Negara" yang sangat kuat sehingga menjadi alasan UU Kehutanan untuk memasukkan hutan adat ke dalam kategori hutan negara. Dalam hal ini, MK (2013: 170) berpendapat: “...berlakunya norma yang tidak menjamin kepastian hukum dan menimbulkan ketidakpastian hukum dan menimbulkan ketidakadilan terhadap masyarakat hukum adat dalam kaitannya dengan hutan sebagai sumber-sumber kehidupan mereka, karena subjek hukum yang lain dalam Undang-Undang a quo memperoleh kejelasan mengenai hak-haknya atas hutan. Masyarakat hukum adat berada dalam posisi yang lemah karena tidak diakuinya hak-hak mereka secara jelas dan tegas ketika berhadapan dengan negara dengan hak menguasai yang sangat kuat. Seharusnya penguasaan negara atas hutan digunakan untuk mengalokasikan sumber daya alam secara adil demi sebesar-besarnya kemakmuran rakyat".

\section{Pengaruh Putusan MK 35 terhadap UU Desa}

Sebelum keluarnya putusan MK 35, telah berlangsung proses legislasi yang pengaturannya berkaitan dengan pengakuan dan penghormatan masyarakat hukum adat dan hak ulayatnya, yakni: Rancangan Undang-Undang tentang Desa (RUU Desa) dan Rancangan Undang-Undang tentang Pengakuan dan Perlindungan Hak Masyarakat Hukum Adat (RUU PPHMHA) Dari kedua RUU tersebut, hanya RUU Desa yang saat ini telah disahkan menjadi UU Desa No.6 Tahun 2014. RUU Desa ini secara resmi dibahas oleh DPR setelah Presiden Susilo Bambang Yudhoyono mengeluarkan Amanat Presiden (Ampres) padal tanggal 4 Januari 2012 dan kemudian disahkan menjadi UU pada tanggal 15 Januari 2014. Sedangkan RUU PPHMHA sampai saat ini belun disahkan menjadi undangundang, meski Presiden SBY juga telah mengeluarkan Amanat Presiden pada tanggal 27 Mei 2013 dengan menunjuk Kementerian Kehutanan sebagai kordinator, namun hingga masa periode DPR RI 2009-2014 berakhir, RUU ini gagal disahkan menjadi undang-undang.

Sejak awal proses penyusunan Rancangan Undang-Undang Desa, nomenklatur mengenai pengakuan dan perhormatan terhadap masyarakat hukum adat dan hak-hak tradisionalnya menjadi salah satu yang akan dinormakan sebagai konsekuensi dari implementasi Pasal 18B ayat (2) yang menjadi landasan yuridis. Hal mana tercermin dari Naskah Akademik yang disusun secara bersama-sama oleh Kementerian Dalam Negeri 
dan organisasi masyarakat sipil yang di dalamnya termasuk aktivis dan pendukung Aliansi Masyarakat Adat Nusantara. Hanya saja, sejuah ini belum ada peraturan perundangundangan yang terbentuk yang benar-benar mengimplementasikan amanat dari Pasal 18B ayat (2) UUD 1945.

Pasca amandemen Pasal 18 UUD 1945 yang kemudian melahirkan Pasal 18B ayat (2) sesunggunya terdapat suatu persoalan penting yang berkaitan dengan pengakuan dan penghormatan masyarakat hukum adat yang sebelum lahirnya putusan MK 35 terus menjadi perdebatan yang belum mendapatkan kepastian secara hukum (konstitusional) yang kemudian dapat menjadi rujukan bagi pembentukan perundang-undangan, yakni: mengenai siapa yang disebut dengan kesatuan masyarakat hukum adat, bagaimana proses pengakuan dan penghormatan masyarakat hukum adat, dan apa unit sosial dari masyarakat hukum adat. Perdebatan ini masih tetap berlangsung hingga proses legilasi RUU Desa dan dan RUU PPHMHA sedang berjalan di DPR RI.

Sebagaimana diakui oleh Zakaria (2012) dalam Fauzi, dkk (2014) bahwa salah satu alasan mengapa Pasal 18 (lama) dan juga Pasal 18B ayat (2) pasca amandemen tidak kunjung terealisasikan sebagaimana mestinya adalah karena belum adanya kesempakatan para pihak tentang siapa yang dimaksud dengan 'kesatuan masyarakat hukum adat' dan makna dua kondisionalitas yang menyertai pengakuan dan penghormatan hak-hak tradisional dari kesatuan masyarakat hukum adat. Perdebatan tersebut juga menjadi persoalan yang mengemuka dalam proses pembahasan dan perumusan RUU Desa. Karena beberapa pasal yang berkaitan dengan pengakuan dan penghormatan atas asal-usul yang melekat pada kesatuan masyarakat hukum adat yang dikonsepsikan sebagai kewenangan bagi "desa adat" dalam RUU Desa ini, sempat ditunda pembahasannya karena untuk mendapatkan kejelasan mengenai siapa kesatuan masyarakat hukum adat perlu dilakukan rapat konsultasi antara kementerian yang terkait, seperti Badan Pertanahan Nasional dan Kementerian Kehutanan.

Karenanya, dengan adanya putusan MK 35 ini dinilai pada momentum yang tepat dan sekaligus menjadi jawaban terhadap beberapa perdebatan berkaitan dengan pengakuan dan penghormatan masyarakat hukum adat. Putusan MK 35 yang meskipun pokok perkaranya berkaitan dengan dikeluarkannya hutan adat dari kategori hutan negara, namun dalam pandangan beberapa peneliti bahwa putusan tersebut dapat menjawab perdebatan yang selama ini mengemuka terkait dengan siapa yang disebut kesatuan masyarakat hukum adat, bagaimana proses pengakuan dan perlidungan masyarakat hukum dan apa unit sosial masyarakat hukum adat (Fauzi, dkk 2014; Zakaria 2014; Arizona 2014; Siscawati 2014). Menurut Zakaria (2014: 101) Putusan MK 35 telah menjadi rujukan dalam perumusan UU Desa. Secara khusus putusan MK 35 ini menjadi pegangan konstitusional dalam menyusun regulasi yang terkait dengan penetapan kriteria dan proses perlindungan masyarakat hukum adat. Karena kalau dicermati dengan seksama, Putusan MK 35 ini, keputusan pokoknya tidak hanya berkaitan dengan bahwa hutan adat bukan bagian dari hutan negara, tetapi mengandung sejumlah proposisi yang berkaitan erat dengan pengakuan dan keberadaan masyarakat hukum adat, yang juga sekaligus memberi arahan konstitusional bagi implementasi Pasal 18B ayat (2) UUD 1945.

Lebih jauh Zakaria (2014) menjelaskan bahwa melalui putusan MK 35 ini setidaknya terdapat lima pelajaran penting terkait dengan konsep-konsep pengakuan dan perlindungan
Tabel 1. Keterkaitan Putusan MK 35 dan UU Desa

\begin{tabular}{|c|c|}
\hline Putusan MK 35 & $\begin{array}{c}\text { UU No.6/2012 tentang } \\
\text { Desa }\end{array}$ \\
\hline $\begin{array}{l}\text { Hutan Adat Bukan Hutan } \\
\text { Negara }\end{array}$ & $\begin{array}{l}\text { Desa Adat adalah MHA } \\
\text { (Pasal 96) }\end{array}$ \\
\hline $\begin{array}{l}\text { Hutan adat berada dalam } \\
\text { wilayah adat Masyarakat } \\
\text { Hukum Adat }\end{array}$ & $\begin{array}{l}\text { Kewenangan Desa adat } \\
\text { (Pasal 103), khususnya } \\
\text { berkaitan dengan } \\
\text { pengurusan wilayah ulayat } \\
\text { atau adat }\end{array}$ \\
\hline $\begin{array}{l}\text { Masyarakat Hukum Adat } \\
\text { ditetapkan Melalui Perda }\end{array}$ & $\begin{array}{l}\text { Penetapan Desa adat } \\
\text { melalui Perda (98) }\end{array}$ \\
\hline $\begin{array}{l}\text { Dengan Kriteria yang telah } \\
\text { diputuskan oleh MK }\end{array}$ & $\begin{array}{l}\text { Kriteria Desa Adat (Pasal } \\
\text { 97) }\end{array}$ \\
\hline
\end{tabular}

masyarakat hukum adat yang kemudian menjadi rujukan penyusunan Rancangan Undang-Undang Desa, yakni: Pertama, bahwa putusan MK 35 ini menegaskan masyarakat hukum adat sebagai subjek hukum. Kedua, masyarakat hukum adat adalah desa atau disebut dengan Nama lainnya. Ketiga, masyarakat hukum adat berhak menguasai wilayah ulatyatnya. Keempat, masyarakat hukum adat itu dinamis dan tidak statis, dan kelima, keberadaan masyarakat hukum adat itu cukup dibuktikan dengan peraturan di tingkat kabupaten.

Dengan demikian bahwa kehadiran Putusan MK 35 yang kedudukannya sebagai penegasan kembali norma konstitusi terhadap pengakuan dan penghormatan terhadap masyarakat hukum adat sebagaima termaktub pada Pasal 18B ayat (2) UUD 1945, selain memberi arahan mengenai konsepsi-konsepsi hukum berkaitan dengan pengakuan dan perlindungan masyarakat hukum adat terhadap proses legislasi Rancangan Undang-Undang Desa yang sedang berjalan di DPR RI, juga secara teknis membantu pembuat kebijakan dalam proses percepatan konsolidasi gagasan yang akan dituangkan dalam pasal-pasal nantinya. Dalam hal ini Putusan MK 35 berperan untuk meyakinkan para pembuat kebijakan mengenai eksistensi masyarakat hukum adat sebagai subjek hukum yang mempunyai wilayah yang diurusnya sendiri berdasarkan hak asal usul.

Undang-Undang Nomor 6 tahun 2014 tentang Desa membuat suatu aturan khusus mengenai desa adat yang termuat dalam Bab XIII, Pasal 96-111. Dasar Filosofis dari ketentuan khusus mengenai desa adat ini adalah bersumber dari Pasal 18 B ayat (2) UUD 1945, dan penegasan dari Putusan Mahkahmah Konstitusi Nomor 35 tahun 2012 menjadi dasar yuridisnya. Tentu saja tak kalah pentingnya untuk disebutkan bahwa ketentuan desa adat dalam UU Desa ini secara sosiologis merupakan hasil dari perjuangan panjang dari gerakan masyarakat hukum adat berserta dengan pendukungnya. Namun demikian, pengakuan konstitusional Pasal 18B ayat (2) UUD 1945 dan penegasan norma konstitusi tersebut melalui Putusan MK 35 ini, tidak akan implementatif jika diatur dalam peraturan perundangundangan sebagaimana diatur dalam Pasal 10 ayat (1) dan (2) UU No.12 tahun 2011 tentang Pembentukan Peraturan Perundang-undangan. Maka sesungguhnya UU No.6 tahun 2014 tentang Desa yang di dalamnya mengatur ketentuan khusus tentang desa adat merupakan undang-undang pertama yang menindaklanjuti ketentuan Pasal 18B ayat (2) UUD 1945 dan Putusan Mahkamah Konstitusi Nomor 35 Tahun 2012.

Pengaturan secara khusus mengenai desa adat dalam UU Desa ini menunjukkan bahwa perdebatan konsepsi-konsepsi 
mengenai pengakuan dan perlidungan masyarakat hukum adat akhirnya bisa diatasi melalui Putusan MK 35 yang kemudian oleh pembuat kebijakan mengadopsi menjadi norma-norma hukum yang mengatur kesatuan masyarakat hukum adat Cq. desa adat sebagaimana yang terjadi dalam UU No.6 tahun 2014 tentang Desa (Fauzi, dkk 2014: 18). Pokok-pokok pengaturan dalam Bab XIII terdiri dari empat kelompok pengaturan, yakni: 1) Pengaturan tentang penataan desa adat yang terdiri atas penetapan, pembentukan (termasuk di dalamnya penggabungan dan penghapusan), dan penataan; 2) Wewenang desa adat; 3) Pemerintahan dan peraturan desa adat, dan 4) Hubungan antara pengatura di Bab XIII (Pasal 96-111) dengan pasal-pasal lain dalam Undang-Undang Desa.

\section{Pengaruh Putusan MK 35 terhadap RUU PPMHA}

Rancangan Undang-Undang Pengakuan dan Perlindungan Hak-Hak Masyarakat Hukum Adat (RUU PPHMHA) secara resmi dibahas di DPR setelah Presiden Susilo Bambang Yudhoyono mengeluarkan Amanat Presiden (Ampres) No. R-20 pada tanggal 27 Mei 2013. Ampres ini menunjuk empat kementerian yakni Kementerian Kehutanan (Sekarang: Kementerian Lingkungan Hidup dan Kehutanan) sebagai kordinator bersama, Kementerian Dalam Negeri, Kementerian Energi dan Sumber Daya Mineral dan Kementerian Hukum dan HAM untuk mewakilipemerintah dalam membahas RUU ini bersama DPR RI.

Sebelum RUU ini menjadi inisiatif DPR RI, AMAN bersama jaringan pendukungnya telah mengupayakan proses advokasi dan konsolidasi gagasan serta konsolidasi gerakan untuk menyusun Naskah Akademik versi CSO. Bermula dari sejumlah gelaran diskusi, seminar dan workshop yang diselenggarakan oleh AMAN sejak tahun 2004 hingga menjadi keputusan organisasional pada Kongres AMAN yang ke-3 di Pontianak pada tahun 2007. Berdasar dari mandat organisasi inilah, pengurus AMAN melakukan sejumlah upaya advokasi hingga membuahkan hasil, dimana Rancangan UndangUndang Pengakuan dan Perlindungan Hak-Hak Masyarakat Hukum Adat masuk dalam Program Legislasi Nasional (Prolegnas) 2009-2014, meskipun pembahasannya baru dimulai tahun 2013.

Mengamati diskusi yang berkembang dari berbagai forum yang diselenggarakan oleh AMAN beserta jaringan pendukungnya, RUU Pengakuan dan Perlindungan Masyarakat Adat ini didasari latar belakang sebagai berikut: Pertama, realitas persoalan sosial, ekonomi, politik dan budaya berupa kemiskinan, marginalisasi dan penyingkiran yang dihadapi oleh komunitas-komunitas anggota AMAN hampir secara merata terjadi yang pada akhirnya menimbulkan kesadaran kritis untuk menunut perbaikan regulasi yang dianggap sebagai salah satu penyebab dari masalah-masalah tersebut, sementara di sisi lain komunitas-komunitas yang mengatasnamakan masyarakat adat ini jumlahnya cukup signifikan dan sebagian besar memandang bahwa terjadi hubungan yang belum selesai antara mereka dengan negara dalam hal pengelolaan sumber daya alam/agraria.

Kedua, disadari bahwa pengaturan mengenai masyarakat adat pada dasarnya telah diatur dalam berbagai peraturan perundangundangan sektoral yang mengatur masalah SDA/agraria, akan tetapi selain subtansi pengaturannya belum memadai juga diperlukan sinkronisasi dan harmonisasi pengaturan, sehingga RUU PPMHAdimaksudkan sebagai undang-undang "payung". Ketiga, sejalan dengan upaya sinkronisasi dan harmonisasi pengaturan mengenai SDA/Agraria, juga dimaksudkan untuk menyelesaikan persoalan konsepsional terkait dengan definisi, kriteria dan siapa yang disebut masyarakat hukum adat. Kalangan CSO khususnya AMAN sangat berkepentingan menyelesaikan persoalan-persoalan tersebut melalui RUU ini karena di beberapa pengaturan dianggap masih bermasalah, khususnya bagi anggota AMAN di wilayah, Misalnya kritik AMAN terhadap pengakuan bersyarat dari negara, atau cara pemerintah mengatur mengenai identifikasi masyarakat adat, juga termasuk soal definisi dan penyebutan istilah. Keempat, sejak era desentralisasi dan sebagian besar peraturan perundang-undangan memberi peluang hukum pengakuan dan perlindungan MA melalui peraturan daerah, tetapi kalangan aktivis masyarakat adat menganggap kurang kuat jika pengaturannya tidak pada level undang-undang.

Secara keseluruhan materi RUU PPMHA terdiri dari 11 Bab, 58 Pasal dan 86 ayat, yang mencakup hal-hal berikut: pengertian dan definisi masyarakat hukum adat, ruang lingkup pengakuan dan perlindungan yang didalamnya mencakup cara identifikasi, verifikasi dan pengesahan masyarakat hukum adat, sejumlah hak dan kewajiban masyarakat hukum adat, mekanisme penyelesaian sengketa, kelembagaan masyarakat hukum adat. ${ }^{2}$

Materi RUU PPMHA tersebut di atas tidak banyak mengalami perubahan pasca keluarnya putusan MK 35. Hal ini disebabkan karena baik RUU PPMHA maupun materi guguatan judicial review terhadap UU No.41 tahun 1999 tentang Kehutanan didasarkan pada landasan konstitusional yang sama, yakni pasal 18B ayat (2) UUD 1945. Dalam RUU PPMHA, Pasal 18B ayat (2) UUD 1945 digunakan dasar bagi pengakuan dan perlindungan masyarakat hukum adat, artinya RUU ini diarahkan sebagai bentuk dari implementasi dari norma konstitusi tersebut, sedangkan dalam gugatan judicial review, AMAN menunjukkan bahwa selama ini implementasi UU Kehutanan sebagai bentuk dari pelanggaran konstitusional dari pengaturan dan pengurusan sumber-sumber agraria di sektor kehutanan. Dalam konteks ini dapat dilihat bahwa judicial review sebagai suatu peluang hukum yang digunakan oleh AMAN untuk dijadikan pintu masuk menguatkan posisi masyarakat adat dalam penguasaan atas wilayah adatnya di sektor kehutanan. Putusan MK 35 meskipun tidak terlalu berpengaruh terhadap subtansi RUU PPMHA, tetapi digunakan oleh AMAN dan jaringan pendukungnya untuk mendorong proses percepatan pembahasan dan pengesahan PPMHA, dan dalam perkembangan advoksi RUU PPMHA ini disosialisasikan sebagai implementasi MK 35.

\section{Analisis Diskursus dan Aktor}

Sebagaimana diulas IDS (2006) dan Sutton (1999) bahwa perumusan kebijakan sangat jauh dari sekedar isu teknis, jawaban dari persoalan yang diidentifikasi, melainkan melibatkan pertentangan aktor-aktor yang terlibat.Lubell (2004) dalam Kartodiharjo (2008) menjelaskan bahwa perumusan kebijakan lebih merupakan kontestasi dari kepentigan politik, pengetahuan dan kekuasaan. Perubahanperubahan kebijakan sangat tergantung pada kemampuan suatu diskursus tertentu apakah dapat membangkitkan ideide baru dan diterima berbagai aktor atau tidak. Pada kasus Undang-Undang Desa dan RUU PPMHA dapat ditemukan bahawa suatu kebijakan tertentu dibangun oleh peran aktif dari berbagai aktor-akademisi, lembaga donor, politisi, LSM, dan lain-lain-serta jaringan yang dapat mereka bangun, sehingga dapat memanfaatkan ruang yang tersedia dalam konteks, situasi, dan waktu tertentu.

2. Laporan Ketua Pansus RUU PPMHA dalam Konsultasi Nasional, 22 Mei 2014. 
Pada pembentukan kebijakan UU Desa, setidaknya terdapat 4 diskursus yang berkembang yang diusung oleh beragam aktor, yakni: Pertama, diskursus pengakuan desa adat yang merupakan penjabaran dari tuntutan pengakuan desa yang beragam sebagai counter terhadap kebijakan penyeragaman desa yang terjadi selama ini. Aktor utama dari diskursus ini adalah aktivis gerakan masyarakat adat bersama aktivis gerakan pembaruan agraria. Kedua, diskursus mengenai pemerintahan desa, dimana UU desa lebih diarahkan mengatur mengenai pemerintahan desa sebagaimana telah diatur pada kebijakankebijakan sebelumnya. Diskursus ini lebih banyak diusung oleh pemerintah yang dipelopori oleh Kementerian Dalam Negeri. Dalam berbagai kesempatan mereka berlawanan dengan aktor yang mengusung desa adat.

Ketiga, diskursus mengenai perbakan posisi kepala desa dan tunjangan yang baik. Diskursus ini diusung oleh para asosiasi kepala desa se-indonesia. Keempat, diskursus demokratisasi pedesaan, perbaikan sistem representasi warga desa, pemberian otononomi penyelenggaraan pemerintahan kepada desa dan alokasi khusus pendanaan. Diskursus ini diusung oleh CSO yang selama ini bekerja di isu pemberdayaan masyarakat desa. Kelima, diskursus penyelenggaraan pembangunan desa dan kawasan perdesaan yang lebih baik. Aktor utama dari diskursus ini adalah para lembaga donor dan pemerintah.

Diantara para aktor yang terlibat dalam proses penyusunan UU Desa tersebut di atas, yang paling keras pertentangannya adalah mereka yang menghendaki UU Desa mengakui keberagaman desa dengan memasukkan desa adat sebagai wujud dari pengakuan terhadap keberagaman versus mereka yang menghendaki UU Desa mengatur pemerintahan desa tanpa ada lagi nomenklatur desa adat. Bagi yang mengusung desa adat mempergunakan Pasal 18B ayat (2) UUD 1945, sedangkan pengusung pemerintahan desa menggunakan Pasal 17 UUD 1945. Walhasil karena dukungan aktor lainnya plus dukungan dari parlemen, akhirnya UU Desa ini lebih mencerminkan kepentingan aktor yang mengusung desa adat. Namun kepentingan pengusung pemerintahan desa juga tidak dihilangkan sama sekali setidaknya tercermin dari Bab IV dari UU Desa.

Sehingga dapat ditarik kesimpulan bahwa meskipun pada fase awal pembentukan UU desa ini terjadi pertentangan kepentingan sangat keras dari pada aktor, namun dalam

Tabel 2. Aktor dan Diskursus dalam UU Desa

\begin{tabular}{|c|c|c|}
\hline Diskursus & Aktor & Hasil \\
\hline $\begin{array}{l}\text { Desa Yang } \\
\text { Beragam/Desa } \\
\text { Adat }\end{array}$ & $\begin{array}{l}\text { CSO (AMAN, } \\
\text { HuMA, Epistema } \\
\text { KARSA, KPA, } \\
\text { Bina Desa) }\end{array}$ & $\begin{array}{l}\text { Pasal } 3 \text { huruf a } \\
\text { dan b; Pasal 6; } \\
\text { Bab XIII; Pasal } \\
19 \text { huruf a dan b; } \\
\text { Pasal } 26 \text { Huruf J }\end{array}$ \\
\hline $\begin{array}{l}\text { Pemerintahan } \\
\text { Desa }\end{array}$ & $\begin{array}{l}\text { Pemerintah } \\
\text { (Depdagri) }\end{array}$ & $\begin{array}{l}\text { Pasal } 4 \text { huruf e; } \\
\text { Bab XIV }\end{array}$ \\
\hline $\begin{array}{l}\text { Perbaikan posisi } \\
\text { kepala desa }\end{array}$ & $\begin{array}{l}\text { Asosiasi Kepala } \\
\text { Desa }\end{array}$ & $\begin{array}{l}\text { Pasal } 33 \text { dan } \\
\text { Pasal } 39\end{array}$ \\
\hline $\begin{array}{l}\text { Demokratisasi } \\
\text { Pedesaan }\end{array}$ & $\begin{array}{l}\text { CSO (IRE. } \\
\text { LAPERA, FPD) }\end{array}$ & $\begin{array}{l}\text { Pasal } 19 \text { huruf a } \\
\text { dan b; Pasal 54, } \\
\text { 56, } 72 \text { dan Pasal } \\
94\end{array}$ \\
\hline $\begin{array}{l}\text { Pembangunan } \\
\text { Desa/Perdesaan } \\
\text { yang baik }\end{array}$ & $\begin{array}{l}\text { Lembaga Donor } \\
\text { dan Pemerintah }\end{array}$ & Bab IX \\
\hline
\end{tabular}

perkembangannya, khususnya ketika UU Desa ini hendak disahkan mulai terjadi kompromi-kompromi dari para aktor. Sehingga subtansi dari UU Desa ini sesungguhnya mencerminkan dari pertarungan dari para aktor dalam proses pembentukan kebijakan.

Sedangkan pada kasus RUU PPMHA, diskursus yang berkembang dan aktor yang terlibat tidak sebanyak seperti dalam UU Desa. Aktor utama dalam RUU ini adalah AMAN beserta dengan jaringan koalisi yang mengusung diskursus pengakuan dan perlindungan masyarakat hukum adat sebagai implementasi dari amanat konstitusi dan sebagai bentuk negara melakukan pemenuhan, pemulihan dan pemajuan HAM. Selain itu, Kementerian Kehutanan yang ditunjuk sebagai Kordinator yang mewakili pemerintah dalam membahas dengan DPR RI menjadi aktor yang dalam proses penyusunan RUU ini mempunyai banyak perbedaan konsepsi mengenai siapa masyarakat adat dan bagaimana bentuk pengakuan terhadap masyarakat hukum adat. Demikian halnya, Kementerian Kehutanan mempunyai pandangan bahwa pengakuan dan perlindungan masyarakat hukum adat harus disertai dengan syarat-syarat yang sesuai dengan peraturan perundangundang, sementara bagi AMAN pensyaratan tersebut sebagai bentuk dari upaya mempersulit bagi masyarakat adat untuk mendapatkan pengakuan.

Di luar persoalan konsepsi-konsepsi di atas, Kementerian Kehutanan sejak awal mempunyai perbedaan pandangan dengan AMAN terkait dengan implementasi Putusan MK 35. Bagi Kementerian Kehutanan mempunyai pandangan bahwa Putusan MK 35 yang menyatakan hutan adat bukan lagi hutan negara diartikan bahwa hutan adat dengan demikian keluar dari kawasan hutan. Pandangan Kementerian Kehutanan ini menunjukkan bahwa hutan negara disamakan dengan kawasan hutan. Berbeda dengan pandangan di atas, AMAN beserta jaringan pendukungnya memadang bahwa hutan adat yang saat ini bukan lagi bagian dari hutan negara tidak berarti bahwa hutan adat bukan bagian dari kawasan hutan. Hutan adat tetap dalam kawasan hutan akan tetapi hutan adat adalah milik masyarakat hukum adat, dengan demikian Pemerintah masih mempunyai kewenangan untuk terlibat dalam proses pemberdayaan kepada masyarakat hukum adat agar fungsifungdi kehutanannya bisa berjalan dengan baik.

Dalam konteks ini dapat dipahami mengapa RUU PPMHA tidak jadi disahkan menjadi UU pada masa akhir DPR periode 2009-2014 meskipun dalam posisinya sama dengan UU Desa sebagai bentuk implementasi dari Putusan MK 35. Tentu saja kendalanya bukan perkara teknis di DPR, namun gagalnya RUU PPMHA ini karena dua hal: Pertama, karena belum adanya kesepahaman dari para aktor yang terlibat dalam pembentukan kebijakan terkait masalah definisi masyarakat adat, unit sosial dan wilayah adat, dan Kedua, lemahnya jaringan AMAN di parlemen dan pemerintah sehingga susah memberi pengaruh lebih kuat atas argumentasi yang dibangun terkait dengan pengakuan dan perlindungan.

\section{KESIMPULAN DAN SARAN}

\section{Kesimpulan}

Dari hasil penelitian ini didapati, bahwa: 1) Gerakan masyarakat adat Indonesia yang dalam hal ini direpresentasikan Aliansi Masyarakat Adat Nusantara (AMAN) mengalami kebangkitan kembali karena faktor kesempatan politik yang terbuka pasca reformasi dan berhasil menyuarakan keresahan-keresahan di tingkat lokal ke arena nasional. 2) AMAN sebagai reprsentasi 
dari komunitas-komunitas lokal mencoba melakukan gugatan terhadap UU Kehutanan yang dinilai merampas wilayahwilayah adat (hutan) mereka, dan menghasilkan Putusan MK 35 yang mengeluarkan hutan adat dari kategori hutan negara. 3) Putusan MK 35 ini merupakan penegasan norma konstitusi terhadap pengakuan dan perlindungan masyarakat hukum adat dengan memutuskan bahwa masyarakat hukum adat adalah subjek hukum, penyandang hak dan pemilik wilayah adatnya. 4) Putusan MK 35 ini telah memberi pengaruh terhadap subtansi pembentukan kebijakan, yakni pada Undang-Undang Desa dan Rancangan Undang-Undang Pengakuan dan Perlindungan Masyarakat Hukum Adat. 5) Peran dan posisi aktor sangat mempengaruhi bagaimana suatu kebijakan tersebut dapat terbentuk atau tidak terbentuk, dalam hal ini adanya kompromi dari kepentingan dari para aktor yang terlibat dalam penyusuna UU Desa menghasilan adanya nomenklatur desa adat dalam UU Desa, sedangkan dalam kasus RUU PPMHA, kepentingan para aktor sulit dipertemukan dan ketidakjelasan dari diskursus unit sosial sebagai basis pengakuan masyarakat adat belum jelas sehingga RUU ini gagal untuk disahkan.

\section{DAFTAR PUSTAKA}

Arizona, Yance [Peny.]. 2010. Antara Teks dan Konteks;Dinamika Penegakan Hukum Terhadap Hak Masyarakat Adat atas Sumber Daya Alam di Indonesia. Jakarta (ID): HuMA.

2014. Dibutuhkan Pengakuan Hukum Terintegrasi: Kajian Hukum Penerapan Putusan MK Nomor 35/PUU-X/2012 Terhadap Peraturan Daerah Kabupaten Malinau Nomor 10 Tahun 2012 tentang Pengakuan dan Perlindungan Hak-Hak Masyarakat Adat di Kabupaten Malinau. Junrnal Wacana XVI (33): 137-158. , Siti Rakhma Mar May Herwati, Erasmus
Cahyadi. 2014. Kembalikan Hutan Adat Kepada Masyarakat Hukum Adat: Anotasi Putusan Mahkamah Konstitusi Perkara No.35/PUU-X/2012 mengenai Pengujian Undang-Undang Kehutanan. Jakarta (ID): Perkumpulan HuMa Indonesia, Epistema Institute, Aliansi Masyarakat Adat Nusantara.

Davidson, Jamies S, David Hanley dan Sandra Moniaga. 2010. Adat dalam Politik Indonenesia. Jakarta (ID): Yayasan Obor Indonesia.

Fauzi, Noer. 2005. Memahami Gerakan-Gerakan Rakyat Dunia Ketiga. Yogyakarta (ID): Insist Press. 2003. Bersaksi untuk Pembaruan Agraria, Dari Tuntutan Lokal hingga Kecenderungan Global. Yogyakarta (ID): KARSA bekerjasama KPA.

[IDS] Institute of Development Studies. 2006. Understanding Policy Processes; A Review of IDS Research on the Environment. United Kingdom: University of Sussek Brighton.

Kartodihadjo, Hariadi. 2013. Hutan Negara di Dalam Wilayah Masyarakat Hukum Adat; Doktrin, Fakta dan Implikasinya bagi Kelestarian Hutan [Makalah].

Rachman, Noer Fauzi, Mia Siscawati. 2014. Masyarakat Hukum Adat adalah Penyandang Hak, Subjek Hukum, dan Pemilik Wilayah Adatnya: Memahami secara Kontekstual Putusan Mahkamah Konstitusi Republik Indonesia atas Perkara Nomor 35/PUU-X/2012. Yogyakarta (ID): Insist Press.

Sutton, R. 1999. The Policy Proccess; An Overview[Working Paper 118] London: Overseas Development Institute.

Zakaria R.Yando. 2014. Kriteria Masyarakat (Hukum) Adat dan Potensi Implikasinya Terhadap Perebutan Sumberdaya Hutan Pasca Putusan MK Nomor 35/ PUU-X/2012: Studi Kasus Kabupaten Kutai Barat, Kalimantan Timur. Junrnal Wacana XVI (33): 99-135 